
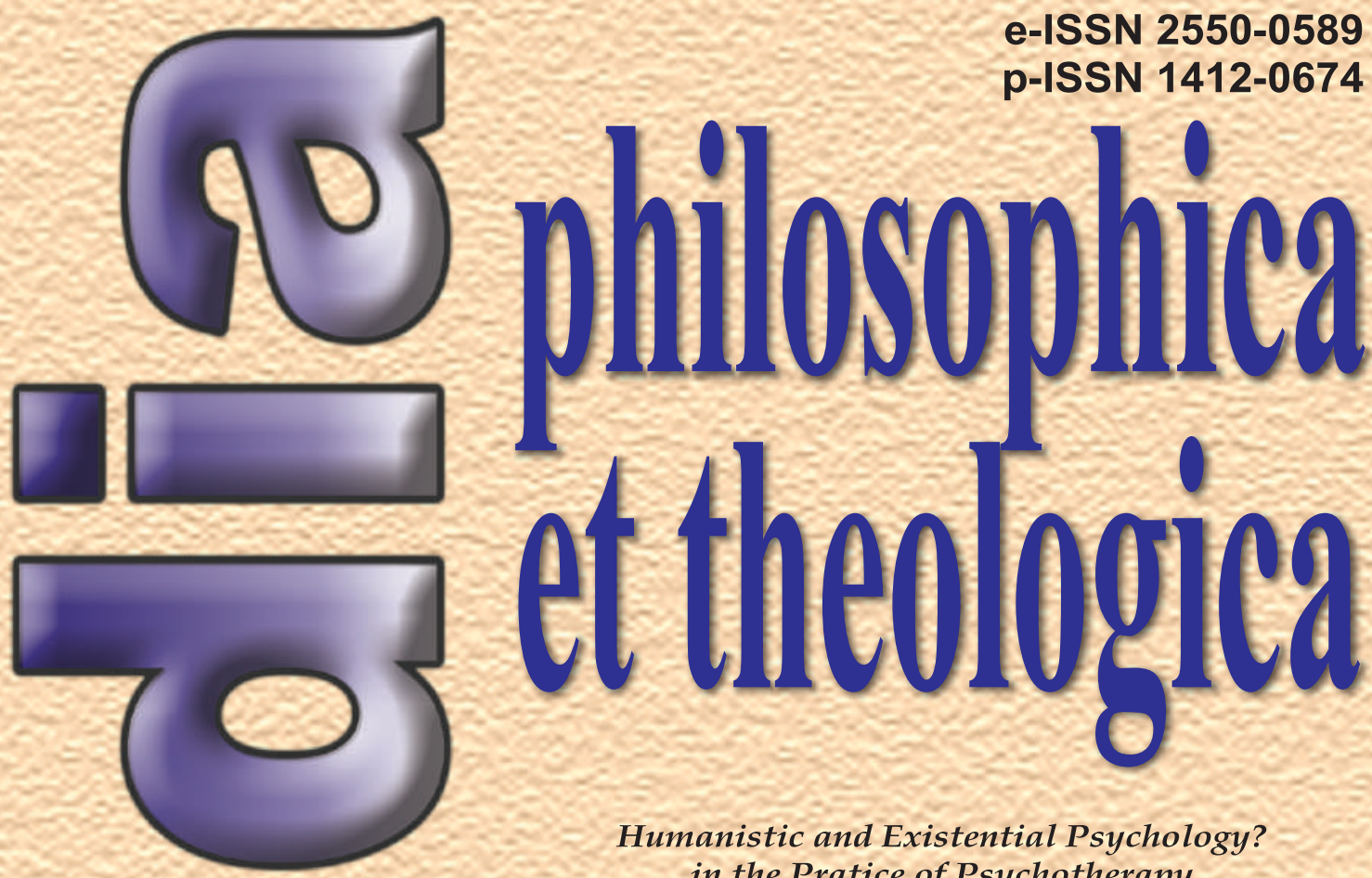

Humanistic and Existential Psychology? in the Pratice of Psychotherapy Aureliano Pacciolla

Visi Eskatologi - Kreatif da Eksemplaris - Terbuka Christanto Sema Raffan Paledung

Tentang Harmoni Antara Tuhan, Manusia dan Alam Dalam Tradisi Beduruk Di Dusun Medang Fransiskus Gregorius Nyaming
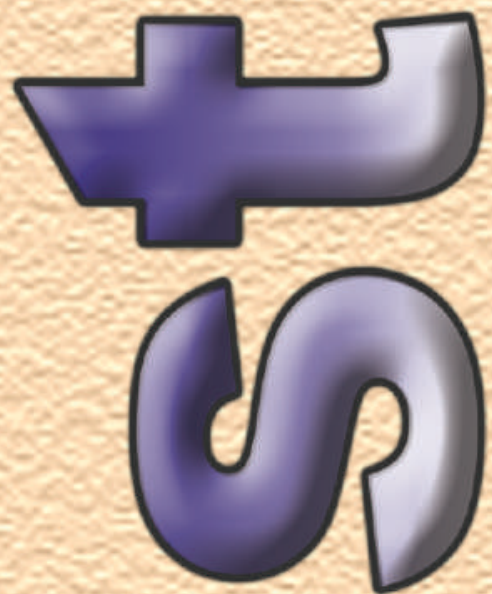

Tergeraklah Hatinya oleh Belas Kasihan Belajar dari Perumpamaan Orang Samaria yang Murah Hati (Luk. 10:25-37) Benny Phang

Hutan Dibabat, Masyarakat Melarat, Masa Depan Gelap I Ketut Gegel

Awal Moral Kristiani Edison R.L. Tinambunan $* * * * *$

TELAAH BUKU

Sekolah Tinggi Filsafat Teologi

Vol. 19 No. 1 April 2019 Widya Sasana, Malang 


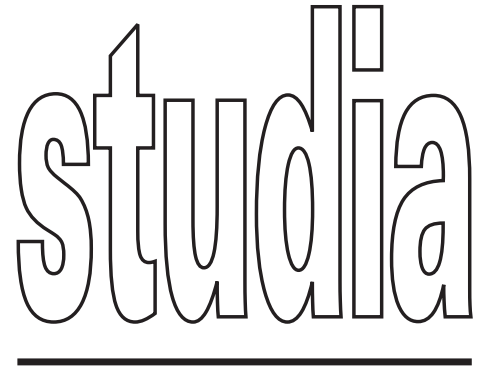

STUDIA PHILOSOPHICA ET THEOLOGICA (ISSN Print 1412-0674 and ISSN Online 2550-0589) is a bilingual (Indonesian and English language) and peer reviewed journal published by Center of Research of Widya Sasana School of Philosophy Theology, Malang. STUDIA specializes in researched papers related to contextualization and inculturation of theology and philosophy from inter-disciplinary-methodological point of view. Journal has 2 issues per year (April and October).

STUDIA welcomes philosophical and theological contributions from scholars with various background of disciplines. This journal uses English and Indonesian Language. STUDIA is an open access journal whose papers published is freely downloaded.

\section{FOCUS AND SCOPE:}

STUDIA focuses on philosophical and theological studies based on both literary and field researches. The emphasis of study is on systematic attempt of exploring seeds of Indonesian philosophy as well as contextualization and inculturationof theology in socio-political-historical atmosphere of Indonesia.

Scope of STUDIA covers various perspectives of philosophical and theological studies from interdisciplinary methodology and cultural-religious point of view of traditions.

\section{PUBLISHER :}

P3M Sekolah Tinggi Filsafat Teologi

Widya Sasana Malang

Jl. Terusan Rajabasa 2,

Malang 65146 Indonesia

Telp. $0341-552120$

Fax. $0341-566676$

Email : stftws@gmail.com

Website : ejournal.stftws.ac.id
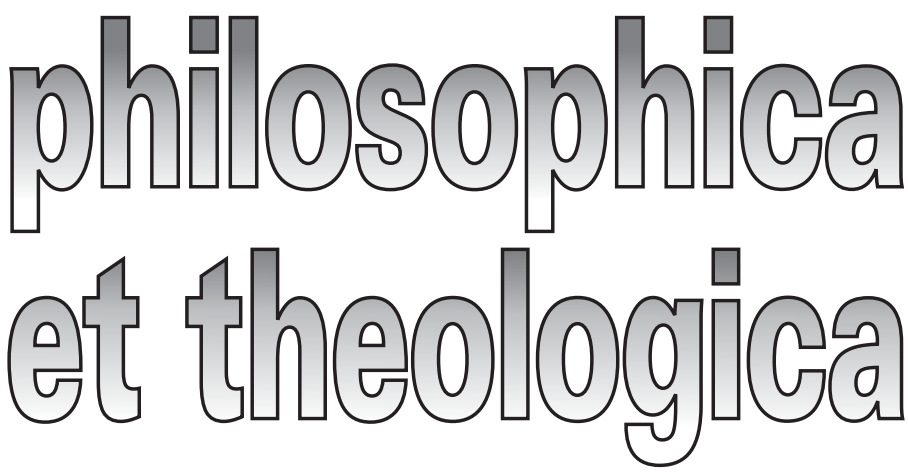

e-ISSN 2550-0589
p-ISSN 1412-0674

Editor

Edison RL. Tinambunan (Google Scholar; h-index: 1); Widya

Sasana College of Philosophy Theology, Malang. (Editor-in-Chief)

\section{Editorial Board}

FX. Eko Armada Riyanto (Google Scholar; h-index: 5); Widya Sasana College of Philosophy Theology, Malang.

Kurniawan Dwi Madyo Utomo (Google Scholar); Widya Sasana College of Philosophy Theology, Malang.

Pius Pandor (Google Scholar; h-index: 2); Widya Sasana College of Philosophy Theology, Malang.

Valentinus Saeng (Google Scholar; h-index: 2); Widya Sasana College of Philosophy Theology, Malang.

Yohanes I Wayan Marianta (Google Scholar); Widya Sasana College of Philosophy Theology, Malang.

Raymundus Made Sudhiarsa (Google Scholar; h-index: 2); Widya Sasana College of Philosophy Theology, Malang.

Alphonsus Catur Raharso (Google Scholar; h-index: 2); Widya Sasana College of Philosophy Theology, Malang.

Petrus Maria Handoko (Google Scholar; h-index: 2); Widya Sasana College of Philosophy Theology, Malang.

Antonius Denny Firmanto (Google Scholar; h-index: 2); Widya Sasana College of Philosophy Theology, Malang.

Carl Sterkens (Scopus ID: ... ; Google Scholar; h-index: 7); Katholic Radboud University, Nijmegen, Niederlands.

Daniel Franklin Pilario(Google Scholar; h-index: 4); Adamson University, Manila, Philippines.

Roland Tuazon (Google Scholar; h-index: 2); Adamson University, Manila, Philippines.

Emanuel P.D. Martasudjita (Scopus ID: 6026801; Google Scholar; h-index: 4); Sanata Dharma University, Yogyakarta.

Johanis Ohoitimur (Google Scholar; h-index: 3); Pineleng College, Manado.

Antonius Eddy Kristiyanto (Google Scholar; h-index: 5); Driyarkara College, Jakarta.

Mudjia Rahardja (Scopus ID: ... Google Scholar; h-index: 10); Maulana Malik Ibrahim Islamic State University, Malang.

Justinus Sudarminta (Google Scholar; h-index: 7); Driyarkara College, Jakarta.

\section{English Language Advisor}

Maria Lichmann (North Carolina)

Odilia Rahayu Widji Astuti

\section{Indonesian Language Advisor}

Didik Bagiyowinadi

\section{Information and Technology}

Imilda Retno Arum Sari

\section{Publication Frequency}

Studia Philosophicaet Theologica is published two times a year (April and October) 


\section{Author Guidelines}

1. Article must have150-word abstract in both English and Indonesian language and four or five keywords.

2. Article should be between 5000 and 8000 words, inclusive of references and footnotes.

3. Article must be a study based on either literary (text) or field research.

4. Article will be submitted in Word (single-spaced and 12-point font) for consideration by email attachment, beside online submission as required. Authors must log in before submit their article.

5. Headings:

- First-level headings (e.g. Introduction, Conclusion) should be in bold, with an initial capital letter for any proper nouns.

- Second-level headings should be in bold italics, with an initial capital letter for any proper nouns.

- Third-level headings should be in italics, with an initial capital letter for any proper nouns.

6. Notes and Bibliographies please click https://www.dropbox.com/s/y2nb9l3cvb9 fg47/Notes\%20and\%20Bibliography\%20Turabian\%20Style.pdf? $d l=0$.

7. Article submitted will be peer-reviewed by qualified academics; this process may take weeks or months. All submitted papers are subject to review of the editors, editorial board, and reviewers.

8. Author should be willing to respond to questions from readers of their articles; and in case there is correction, author must refine the article as soon as possible.

\section{Guidelines for Book Reviews}

1. Please include, at the beginning: Author, Title, Place, Publisher, Date, number of pages, ISBN of the book reviewed.

E.g., Taylor, Charles. A Secular Age. Cambridge: The Belknap Press of Harvard University Press, 2007. 874+x pp. ISBN-13: 978-0-674-02676-6.

2. The review begin with abstract, three or four keywords and continue with a brief overall description of the book.

3. The review may include:

- The content and its complexity of the book.

- Comments on the author's style and contribution of the book.

- Philosophical or theological methodology of presentation.

- Position of the philosophical or theological arguments in its field.

4. The preferred format for submissions is MS-Word.

5. Review should be about 1500 words long. The name, affiliation and email address of the reviewer should appear at the end of the review. 


\section{Studia Philosophica et Theologica E-ISSN 2550 - 0589 \\ ISSN 1412-0674 \\ Vol. 19 No. 1 April 2019 \\ Hal. 1 - 118}

\section{DAFTAR ISI}

\section{ARTIKEL}

Humanistic and Existential Psychology

in the Pratice of Psychotherapy

Aureliano Pacciolla

Visi Eskatologis - Kreatif dan Eksemplaris - Terbuka

Sebagai Model Kehadiran Kristen dalam Konteks Indonesia

Christanto Sema Raffan Paledung

Tentang Harmoni Antara Tuhan, Manusia dan Alam

Dalam Tradisi Beduruk Di Dusun Medang

Fransiskus Gregorius Nyaming

Tergeraklah Hatinya oleh Belas Kasihan: Belajar dari

Perumpamaan Orang Samaria yang Murah Hati (Luk. 10:25-37)

Dalam Mengasihi Embrio Manusia Sebagai Sesama

Benny Phang

$57-79$

Hutan Dibabat, Masyarakat Melarat, Masa Depan Gelap

Refleksi Teologis atas Keberpihakan Gereja Terhadap Masyarakat

Dalam Upaya Pelestarian Alam

I Ketut Gegel

Awal Moral Kristiani

Edison R.L. Tinambunan.

$98-114$ 


\section{TELAAH BUKU}

Relasionalitas Filsafat Fondasi Interpretasi:

Aku, Teks, Liyan, Fenomena

Donatus Sermada Kelen ........................................................ 115 - 118 


\title{
TENTANG HARMONI ANTARA TUHAN, MANUSIA DAN ALAM DALAM TRADISI BEDURUK DI DUSUN MEDANG
}

\section{Fransiskus Gregorius Nyaming ${ }^{1}$}

\begin{abstract}
:
In this paper the author focuses on the theme of harmony by using the Beduruk tradition in Medang hamlet as a starting point for reflection. The harmony in question is harmony between man and God, between man and fellowman and between man and nature. The author believes that so far the beduruk tradition has contributed to the values and wisdoms that are needed to build that harmonies. The emphasis on the theme of harmony actually departs from the author's own concern about the destruction of nature and the environment, especially in Indonesia. Therefore, through this discussion, the authors hope that whatever forms of human work in cultivating nature, always respect the Creator, respect for human dignity, and respect for nature.
\end{abstract}

Keywords: God, man, nature, harmony, beduruk, respect, dignity.

\begin{abstract}
Abstrak
Pada artikel ini, penulis berkonsentrasi pada tema harmoni dengan penggunaan tradisi bedruk di Medang sebagai titik awal pembahasan. Harmoni yang dimaksud adalah antara Tuhan - manusia, manusia - sesama, dan manusia - alam. Penulis percaya bahwa sejauh tradisi bedruk yang telah berkontribusi pada nilai dan kebijakan yang dibutuhkan untuk membangun keharmonisan tersebut. Penekanan tema akan keharmonisan sesungguhnya menjadi perhatian khusus penulis mengenai penghancuran alam dan lingkungan, secara khusus di Indonesia. Oleh sebab itu, melalui tulisan ini, penulis berharap bentuk usaha apa pun dari manusia untuk pemeliharaan alam, selalu menjunjung pencipta, kemanusiaan dan alam.
\end{abstract}

Kata kunci: Tuhan, manusia, alam, harmoni, bedruk, penghargaan dan kelayakan.

1 Penulis adalah mahasiswa John Paul II Catholic University of Dublin. 


\section{Pengantar}

Memaknai kehidupan sebuah komunitas manusia tak bisa dilepaskan dari tradisi yang mereka miliki. Tradisi yang hidup dalam sebuah komunitas manusia tentulah berperan penting dalam menjaga kelangsungan, identitas dan kesatuan komunitas itu sendiri. Karena kedudukannya yang penting tersebut, maka manusia selalu berusaha menjaga agar tradisi itu tetap hidup dan lestari sekalipun dunia semakin maju dan modern. Tradisi itu tetap dipelihara karena manusia meyakini ada nilai-nilai, kebijaksanaan-kebijaksanaan luhur yang terkandung di dalamnya yang layak diwariskan kepada setiap generasi.

Dalam konteks pemahaman demikian, tradisi Beduruk dalam suku Dayak Desa di dusun Medang menarik untuk dikaji. Tradisi ini sudah dipraktekkan sejak zaman leluhur dan masih berlangsung hingga hari ini. Tradisi ini sangat kental dengan pola pikir kolektif dan pola pikir intuitif-emotional. Hal inilah yang membuat tradisi ini menarik untuk dibahas mengingat modernisme seringkali membuat orang berpikir sebaliknya, yakni mengagungkan sikap hidup individualistik serta mengkultuskan rasio. Pola pikir modernisme ini seringkali menjadi penyebab terpinggirnya religiositas dalam ranah kehidupan manusia.

Kentaranya pola pikir kolektif, intuitif-emosional dalam tradisi beduruk, bila mau dicermati lebih dalam, sesungguhnya hendak menunjukkan hasrat terdalam manusia untuk membangun harmoni baik secara vertikal (dengan Tuhan) maupun secara horizontal (dengan sesama manusia) dan yang tak kalah penting harmoni dengan alam. Bagaimana harmoni tersebut dipahami? Bagaimana beduruk menghadirkan harmoni tersebut? Apakah sejauh ini harmoni itu sudah tercipta? Munculnya tema ini juga berangkat dari keprihatinan penulis akan kerusakan hutan dan lingkungan di Indonesia. Kita sering menyebut alam sebagai ibu pertiwi. Artinya, layaknya seorang ibu yang mendatangkan kehidupan, demikian juga alam sungguh mendatangkan kehidupan kepada manusia. Sayangnya, seringkali ibu pertiwi itu menangis karena ulah anak-anaknya yang serakah. Dalam keprihatinan inilah penulis mengangkat tradisi beduruk dengan harapan bahwa warisan-warisan kebudayaan yang terkandung di dalamnya bisa menjadi pedoman serta dapat membangkitkan hasrat dalam diri manusia untuk selalu berusaha membangun hubungan yang harmonis dengan Tuhan, dengan sesama dan dengan alam.

Tulisan ini menjadikan tradisi dan budaya manusia sebagai locus theologicus. Hal ini didasarkan pada keyakinan penulis akan betapa pentingnya kebudayaan dalam tugas pewartaan Injil oleh Gereja kepada seluruh bangsa. Sebab, warta gembira tentang Kristus dan kebudayaan manusia memiliki hubungan yang sangat erat. Konsili Vatikan II 
menegaskan, "Sebab Allah, yang mewahyukan diri-Nya sepenuhnya dalam Putra-Nya yang menjelma, telah bersabda menurut kebudayaan yang khas bagi pelbagai zaman. ${ }^{2}$ Aneka ragam budaya manusia, Konsili Vatikan II melanjutkan, sungguh dapat menjadi medan pewartaan Gereja menyebarluaskan dan menguraikan pewartaan tentang Kristus, untuk menggali dan semakin menyelaminya, serta untuk mengungkapkannya secara lebih baik dalam perayaan liturgi dan dalam kehidupan jemaat beriman yang beraneka ragam. ${ }^{3}$

\section{Karakteristik dari Tradisi Beduruk}

Sebelum masuk ke pembahasan tentang beduruk, terlebih dahulu akan dipaparkan secara ringkas mengenai suku Dayak Desa di dusun Medang, tempat di mana beduruk hidup dan dijalankan. Penduduk di Dusun Medang dinamakan suku Dayak Desa. Dayak Desa sendiri termasuk dalam kelompok Ibanic. Masih ada suku-suku lain yang masuk dalam kelompok ini antara lain: Seberuang, Mualang, Ketungau, Kantuk, Sebuyau, Balau, Remun, Dau, Lemanak, Skrang, Ulu Ai, Undup, Batang Lupar, Selakau, Sebaru. ${ }^{4}$ Kelompok Ibanic memiliki beberapa kesamaan seperti bahasa, motif dan gambar tato, adat-istiadat, musik, senjata, ritus keagamaan, pola dan motif anyaman, tenunan dan ukiran. ${ }^{5}$

Dayak Desa tersebar di tujuh kecamatan: kecamatan Sintang, kecamatan Binjai Hulu, kecamatan Kelam Permai, kecamatan Sei Tebelian, kecamatan Dedai, kecamatan Tempunak dan kecamatan Sepauk. Subsuku Dayak Desa ada juga di kabupaten Sanggau. Mereka merupakan penyebaran dari Dayak Desa di kabupaten Sintang. Mereka pindah ke Sanggau karena mencari lahan yang masih subur dan juga menghindari peperangan antarsuku yakni dengan suku Iban. Dayak Desa di kabupaten Sanggau terdapat di kecamatan Sekadau Hilir, tepatnya bermukim di kampung Tapang Sambas, Tapang Kemayau, Perupuk Mentah, Terentang, dan kampung Baru. ${ }^{6}$

Suku-suku Dayak Desa memiliki banyak kesamaan dalam adatistiadat maupun dalam tata kehidupan sosial. Karena itu, agak sulit untuk mencari perbedaan yang menonjol. Kalau sesama warga Dayak Desa

2 Lumen Gentium (LG), 58.

3 Ibid.

4 Lih. https://ibanology.wordpress.com/2013/11/14/iban-ibanic-and-ketungau. Akses: 3/ 02/2019.

5 Samson, Gawai Adat Ngamik Semengat Padi sebagai Ungkapan Religiositas Dayak Desa (Pontianak: STT Pastor Bonus, 2011), 12.

6 John Bamba (ed.), Keberagaman Subsuku dan Bahasa Dayak (Pontianak: Institut Dayakologi, 2008), 121. 
bertemu atau saling berkunjung, misalnya ketika hari gazvai (pesta ucapan syukur setelah selesai panen padi), mereka tidak akan canggung karena memiliki kesamaan dalam adat-istiadat dan kebiasaan dalam hidup sehari-hari.

Dinamakan sebagai Dayak Desa dapat dilihat dari bahasa yang mereka gunakan. Dalam percakapan sehari-hari banyak dijumpai kata yang diakhiri dengan ' $i$ ' dan ' $a i$ '. Sebagai contoh, kata 'makan' menjadi 'makai, untuk 'berjalan' mereka mengatakannya dengan 'bejalai, 'pulang' menjadi 'pulai. Itulah sebabnya mereka disebut Dayak Desa. Karena banyak kata yang diakhiri dengan ' $i$ ' atau ' $a i^{\prime}$ ', bahasa Dayak Desa disebut bahasa benadai-nadai. Kata nadai sendiri artinya "tidak" atau "tidak ada", sehingga kalau diartikan secara harafiah artinya betidak-tidak.

Berkaitan dengan sistem kekerabatan, suku Dayak Desa menganut prinsip kekerabatan bilateral. Prinsip ini menempatkan hak dan kewajiban laki-laki dan perempuan pada derajat yang sama. Baik lakilaki maupun perempuan memiliki peran yang sama penting dalam tugas kemasyarakatan, mengurus rumah tangga dan mencari nafkah. Aktivitas perladangan merupakan contoh nyata yang menampakkan kalau lakilaki dan perempuan memiliki peran yang sama pentingnya. Dalam aktivitas beduruk yang dibahas dalam tulisan ini akan terlihat dengan jelas di mana tugas dan peran mereka sama pentingnya dan saling melengkapi.

Begitulah gambaran ringkas mengenai suku Dayak Desa di dusun Medang. Sekarang pembahasan akan dilanjutkan mengenai tradisi beduruk itu sendiri. Secara etimologis, kata beduruk berasal dari kata kerja "nuruk". Untuk membantu memahaminya dapat dilihat dari penggunaannya dalam percakapan sehari-hari. Sering warga kampung mengatakan, "Anang ulau nuruk pangan, ilak dibalas ringat". Kurang lebih artinya ialah: "Jangan duluan ganggu, nanti kalau dibalas marah".

Dari kalimat di atas kata "nuruk" dapat diartikan sebagai tindakan inisiatif dari seseorang. Aksi "nuruk" biasanya akan selalu mendapat respon atau balasan dari pihak lain. Dalam pemahaman ini, beduruk dapat diartikan sebagai aktivitas "saling membalas" dalam mengerjakan ladang. Karena aktivas "saling membalas" tersebut selalu melibatkan lebih dari satu pihak, maka beduruk kemudian dapat diartikan sebagai gotong royong oleh beberapa orang dalam mengerjakan ladang.

Terminologi "beduruk" sendiri hanya dikenal di kalangan suku Dayak Desa. Dayak Desa merupakan satu dari ratusan suku yang hidup di bumi Kalimantan. Setiap suku mempunyai tradisi, adat-istiadat dan bahasanya masing-masing. Namun, kegiatan berladang hampir dapat dijumpai di semua suku Dayak di Kalimantan. Cara pengolahan ladang tersebut pun mempunyai kemiripan satu dengan yang lainnya. Khusus untuk kerja 
secara bergotong-royong di ladang, mereka menyebutnya seturut bahasa masing-masing.

Tradisi ini muncul bukan tanpa alasan. Bagi warga di dusun Medang yang mayoritas hidup sebagai petani, ladang merupakan salah satu sumber penghidupan yang sangat penting. Dari ladanglah mereka dapat memperoleh padi yang kemudian diolah menjadi nasi sebagai sumber makanan utama. Kemunculan tradisi beduruk tidak bisa dilepaskan dari proses pengerjaan ladang yang cukup panjang. Setidaknya ada delapan tahap pengolahan ladang yang harus dilewati: 1) memilih lokasi (mangul), 2) menebas (nebas), 3) menebang (nebang), 4) membakar ladang (пипи), 5) mengumpulkan dan membakar kayu-kayu sisa pembakaran (nayak), 6) menanam (nugal), 7) menyiangi (mabau) dan 8) memanen (ngetau). Melihat proses yang cukup panjang dan melelahkan ini rasanya tidak mungkin bila ladang dikerjakan seorang diri saja. Beduruk, kemudian, dipandang oleh warga sebagai jalan keluar yang efektif dan efisien untuk mengolah lahan pertanian.

Lalu, bagaimana praktek beduruk ini dilaksanakan? Beduruk selalu dilaksanakan dalam tahap-tahap pengolahan ladang seperti yang telah disebutkan di atas. Dari kedelapan tahap tersebut, nebas, nebang, nayak, nugal, mabau dan ngetau biasanya dikerjakan dengan cara beduruk. Sementara pada tahap nunu, meskipun memerlukan banyak tenaga, kerelaan dan kesediaan warga lain untuk membantu keluarga yang sedang пипи lebih ditonjolkan. Sekurang-kurangnya ada dua jenis beduruk. Pertama, beduruk setengah hari. Beduruk jenis pertama ini dilaksanakan setelah jam makan siang. Dilaksanakan mulai pada siang hari dengan pertimbangan pada pagi harinya para anggotanya masih pergi menyadap karet (noreh), atau masih mengurus urusan rumah tangga lainnya. Aktivitas beduruk ini berakhir sekitar pukul 16.30. Untuk anggotanya sendiri berkisar antara 5-10 orang. Kedua, beduruk satu hari penuh. Warga di dusun Medang menyebut beduruk jenis ini dengan arisan. Arisan dilaksanakan dua kali dalam seminggu. Sejauh yang penulis amati arisan dilaksanakan pada hari Rabu dan Jumat. Jumlah anggota dalam beduruk jenis kedua ini lebih banyak dari anggota beduruk yang pertama. Anggotanya bisa berkisar antara 15-20 orang. Arisan biasanya dimulai pada pukul 09.00 dan berakhir pada pukul 16.30. Dalam pelaksanaan arisan, setiap anggota akan membawa bekal dari rumah masing-masing. Sementara anggota yang nampil ${ }^{7}$ bertanggung jawab penuh untuk menyediakan lauk-pauk dan sayur-mayur. Baik beduruk jenis pertama maupun beduruk jenis kedua sama-sama melibatkan kaum laki-laki dan perempuan.

7 Istilah ini dipakai oleh warga Medang untuk merujuk kepada anggota yang ladangnya mendapat giliran sedang dikerjakan. 
Dalam prakteknya beduruk dilaksanakan secara bergiliran dari ladang yang satu ke ladang yang lain. Aturannya satu ladang untuk satu hari. Penentuan siapa pertama yang akan nampil merupakan kesepakan dari para anggota beduruk sendiri. Jadwal yang mereka buat dapat dikategorikan sangat fleksibel. Fleksibilitas itu dapat dilihat dimana dalam perjalanan waktu anggota yang satu dapat bertukar jadwal nampil dengan anggota yang lain. Pertukaran jadwal ini dilakukan biasanya dengan anggota yang ladangnya masih memerlukan banyak perhatian.

Beduruk bukan hanya sekadar rutinitas harian. Lebih dari itu, beduruk memiliki fungsi yang sangat penting bagi warga yang terlibat di dalamnya. Menurut penulis, ada dua fungsi yang menonjol dari beduruk, yakni meringankan beban pekerjaan dan mengeratkan tali persaudaraan. Fungsi pertama yang langsung terlihat dari kegiatan beduruk ialah meringankan beban pekerjaan. Berladang adalah pekerjaan yang berat dan melelahkan. Meskipun menjadi pekerjaan utama, perhatian warga tentu juga terbagi dengan urusan lain yang tak kalah penting. Karena itu, beduruk dapat menjadi salah satu cara yang ampuh untuk meringankan pekerjaan tersebut. Dengan mengadakan beduruk tidak hanya menjadikan pekerjaan menjadi lebih ringan, tapi juga membuat proses pengerjaan ladang bisa selesai pada waktunya.

Bahwa beduruk memiliki fungsi untuk mengeratkan tali persaudaraan antarwarga dapat dilihat dari sistem keanggotaan beduruk itu sendiri. Mereka yang membentuk sebuah kelompok beduruk datang dari beberapa keluarga. Beberapa masih memiliki hubungan darah, namun beberapa dari mereka tidak memiliki hubungan keluarga sama sekali. Hal ini hendak menunjukkan bahwa beduruk terbuka untuk siapa saja. Dengan sifat keterbukaan seperti ini, beduruk menyadarkan warga untuk menghargai martabat sesama serta memandang orang lain bukan sebagai lawan, melainkan sebagai saudara dan keluarga sendiri.

Selain beduruk, di kalangan suku Dayak Desa juga dikenal istilah besaup. Besaup juga merupakan bentuk kerja gotong-royong. Namun berbeda dari beduruk. Besaup lebih menonjolkan keikhlasan atau ketulusan dari warga lain untuk membantu mereka yang sungguh memerlukan pertolongan. Jadi, tidak ada kewajiban bagi yang ditolong untuk di kemudian hari membalas bantuan yang ia terima sebagaimana dijumpai dalam aturan beduruk. Besaup biasa dilakukan saat musim panen. Setiap keluarga mempunyai jumlah dan luas ladang yang berbeda-beda. Hal inilah yang kadang menjadi penyebab ketidakseragaman berakhirnya kegiatan memanen di antara warga. Dalam situasi demikian, keluarga atau anggota yang telah selesai memanen akan dengan suka rela membantu keluarga yang lain untuk menyelesaikan panenannya. Contoh lain dari besaup ialah ketika salah satu warga hendak membangun rumah yang baru. Didorong semata-mata oleh rasa kekeluargaan, warga yang lain akan berbondong-bondong datang membantu. 


\section{Harmoni dalam Beduruk}

Setelah memaparkan karakteristik dari beduruk, dalam bagian ini akan disajikan bagaimana harmonisasi dengan Tuhan, dengan sesama dan dengan alam tercipta lewat beduruk. Ketiga jenis harmonisasi ini memiliki kaitan yang sangat erat terutama kalau kita memperhatikan beberapa ritual yang dilakukan dalam tahap-tahap pengerjaan ladang.

Pertama, beduruk sebagai harmonisasi dengan Tuhan. Setidaknya ada tiga proses berladang yang dapat menjadi rujukan bagaimana warga berusaha menjalin relasi yang harmonis dengan Sang Pencipta. Pertama, ialah dalam proses membuka lahan. Sebelum lahan mulai dibuka, ada sebuah ritual yang biasa dilakukan warga Dalam ritual ini, warga akan membuat patung dari kayu (pentik/pantak) ${ }^{8}$, pengusiran roh-roh jahat/ pembersihan lahan (bekibau) ${ }^{9}$ dan pemberian makan/sesajen (pegelak/ bedarak)..$^{10}$ Sesudah pentik dibuat, lalu ayam dikibaskan di atas lahan (bekibau) sambil membaca mantra. Seperti ini bunyi mantranya: "Satu, dua, tiga, empat, lima, enam, tujuh, kami ini mau bekerja, menebas-menebang di sini. Kami mohon berkat, kami minta selamat, agar jangan disimbat ranting kasar, ditimpa kayu besar, terluka pisau simpai, tertimpa kapak bertangkai. Kalau ada yang mau mengacau, kibas dengan sayap, libas dengan ekor, tabrak dengan tubuh, remuk dengan paruh, matikan dengan taji". ${ }^{11}$

Kepada siapa ritual itu disampaikan? Suku Dayak Desa di dusun Medang menyebut Tuhan Pencipta dengan sebutan Petara Raja Juzvata. ${ }^{12}$ Dia-lah yang menciptakan alam semesta dan manusia. Namun, Dia menyerahkan pemeliharaan alam semesta kepada Puyang Gana. ${ }^{13}$ Karena itu, ritual yang disampaikan oleh warga ketika hendak membuka lahan ditujukan kepada Puyang Gana, sang Penguasa tanah dengan tujuan untuk memohon izin kalau mereka akan berladang di lokasi tersebut.

8 Pentik merupakan kayu kecil yang diukir menyerupai manusia.

9 Bekibau diartikan sebagai tindakan pembersihan lahan atau pengusiran roh-roh jahat dengan mengibaskan ayam di atas lahan.

10 Pegelak/bedarak merupakan bahan persembahan yang terdiri antara lain atas nasi, daging ayam, sirih, pinang, pisang, telur ayam, lemang, hati babi.

11 Lih. Valentinus, "Adat Pelestarian Hutan", Minum Dari Sumber Sendiri, Dari Alam Menuju Tuhan, Benny Phang \& Valentinus (eds.) (Malang: STFT Widya Sasana, 2011), 72.

12 Suku-suku Dayak memberikan nama bagi Pribadi yang mempunyai kuasa dan kekuatan itu dalam bahasa masing-masing, misalnya Jubata di Dayak Kanayatn, Duataq di Dayak Jalai-Kendawangan, Duato di Dayak Pesaguan, Duata di Dayak Krio, Tapang di Dayak Kayaan, Alatala di Dayak Taman, Penompa Petara di Dayak Jangkang, Penompa di Dayak Pompakng.

13 Puyang Gana merupakan penjaga bumi. Dialah yang menguasai tanah, air, pepohonan dan binatang. Kepada-Nya warga harus meminta izin untuk memanfaatkan kekayaan alam. Lih. Paulus Florus, "Puyang Gana: Sang Penjaga Bumi", Minum Dari Sumber Sendiri, Dari Alam Menuju Tuhan, Benny Phang \& Valentinus (eds.) (Malang: STFT Widya Sasana, 2011), 80. 
Kedua ialah proses menanam padi (nugal). Proses ini merupakan salah satu peristiwa penting dalam aktivitas berladang. Petani tentu mengharapkan agar benih yang akan mereka tanam bisa tumbuh subur agar menghasilkan panenan yang berlimpah. Untuk itu, ritual kembali menjadi unsur yang sangat penting dalam proses ini. Sebelum mulai menanam (nugal) warga akan berkumpul di suatu tempat. Ritual dipimpin oleh kepala keluarga yang empunya ladang atau yang mewakili. Pemimpin ritual pertama-tama memukulkan bambu ke tanah sebagai tanda memanggil Puyang Gana sambil mengucapkan kata-kata berikut:

O Puyang Gana

Lihatlah kami mau nanam.

Kami mohon padi kami bagus,

masa depan kami senang,

hidup kami nyaman. ${ }^{14}$

Benih-benih yang akan ditanam lalu diperciki dengan darah ayam. Pemercikan dengan darah adalah tanda bahwa benih-benih itu sudah diberkati dan siap untuk ditabur. Ritual kemudian dilanjutkan dengan membuat pegelak (sesajen). Pembuatan sesajen ini merupakan salah satu syarat yang tak boleh diabaikan. Lewat sesajen, warga menghaturkan persembahan kepada Sang Petara sekaligus juga memohonkan berkat atas ladang yang sebentar lagi akan ditanami. Setelah semua ritual selesai, maka aktivitas menanam dimulai. Dalam beberapa kesempatan, mengingat warga di dusun Medang semuanya sudah memeluk agama Katolik, pastor/suster/katekis akan dihubungi untuk memimpin doa berkat atas ladang, benih dan semua yang hadir. Berkat dimohonkan agar seluruh proses penanaman padi (nugal) berjalan dengan lanjar. Biasanya ritus Kristiani akan dijalankan setelah semua ritus adat selesai dilakukan.

Proses ketiga ialah pesta syukur atas hasil panen (Gawai). Pesta syukur ini merupakan pesta besar dalam masyarakat Dayak. Pesta ini juga dikatakan sebagai pesta tutup tahun. Artinya, pesta ini dilaksanakan setelah semua warga selesai memanen ladang mereka. Pada hari yang telah disepakati bersama maka warga akan memulai secara serentak pesta syukur panen tersebut. Sebagai rasa syukur atas hasil panen yang diperoleh, setiap keluarga akan membuat pegelak (sesajen) sebagai bentuk persembahan untuk Sang Petara Raja Juwata, Pencipta semesta alam dan juga kepada Puyang Gana, sang Penguasa tanah.

Pesta syukur ini sedapat mungkin dirayakan dengan meriah dan dinikmati banyak orang. Karena itu, sebuah kampung yang akan mengadakan pesta akan mengundang sanak keluarga dan kerabat di

14 Wawancara dengan Bapak Martinus Indat, salah seorang tokoh adat dan tokoh masyarakat dusun Medang, pada tanggal 5-10 Januari 2013. 
mana pun berada untuk turut bergembira bersama. Menurut Paulus Florus, pesta tutup tahun (gawai) tidak hanya menandai suatu kejadian penting dalam kehidupan mereka, tetapi juga berhubungan dengan pengalaman supernatural warga masyarakat, di samping juga menampilkan teguhnya ikatan komunitas dalam masyarakat. ${ }^{15}$

Sebagai sebuah peristiwa penting dalam kehidupan sebagai petani, pesta tutup tahun ini tidak pernah dipandang hanya sebatas pesta rakyat semata. Pesta ini tidak hanya sekadar untuk makan, minum, menarinari, dll. Lebih dari itu, pesta gawai ini hendak menyadarkan masyarakat bahwa hasil panen yang mereka terima merupakan anugerah dari Tuhan sendiri yang sudah sepatutnya mereka syukuri dan tidak untuk dinikmati seorang diri. Karena itu, karya agung Tuhan itu harus dirayakan. Perayaan itu terwujud dalam liturgi Gereja. Liturgi adalah kenangan akan karya keselamatan Allah dalam sejarah umat manusia, juga sekaligus melalui liturgi Allah mengerjakan karya keselamatan-Nya, sehingga dengan merayakannya umat beriman memandang kehadiran serta karya Yang Ilahi. Konsili Vatikan II menegaskan, “Liturgi itu puncak yang dituju oleh kegiatan Gereja, dan serta-merta sumber segala daya kekuatannya." 16 Namun, liturgi bukan hanya sebatas perayaan saja, melainkan dari perayaan liturgi diharapkan tumbuh kehendak untuk berbuat kebaikan. "Liturgi mendorong umat beriman, supaya sesudah dipuaskan dengan sakramen-sakramen Paska sehati-sejiwa dalam kasih, supaya mereka mengamalkan dalam hidup sehari-hari apa yang mereka peroleh dalam iman." 17

Dari ketiga proses yang telah dipaparkan di atas hendak memperlihatkan satu hal fundamental dari kodrat manusia, yakni sebagai makhluk yang terbuka dan terarah kepada yang transenden. Paham ini mengingatkan kita akan gagasan Karl Rahner yang mengatakan bahwa dimensi transenden dalam diri manusialah yang membuat mereka memiliki keterarahan atau keterbukaan akan Allah (Vorgriff). Dengan gagasan ini Rahner hendak menyatakan bahwa manusia selalu sudah terarahkan kepada yang lain di luar dirinya. Dia terbuka untuk manusia yang lain, juga untuk segala benda di dunia. Namun, yang lebih penting manusia terarah kepada dasar segala yang ada, yakni Nan Mutlak. Oleh Rahner disebut sebagai pengetahuan transendental. Keterarahan pada Allah merupakan dasar segala pengetahuan dan tindakan konkrit. ${ }^{18}$

15 Paulus Florus, "Pesta Rakyat: Kebudayaan Universal”, Manusia Dayak, Orang Kecil yang Terperangkap Modernisasi, Nico Andasputra \& Stepanus Djuweng (eds.) (Pontianak: Institut Dayakologi 1996), 98.

16 Sacrosanctum Concilium, 10.

17 Sacrosanctum Concilium, 10.

18 Bdk. Tom Jacobs, Paham Allah dalam Filsafat, Agama-Agama dan Teologi (Yogyakarta: Kanisius, 2002), 82. 
Ritual-ritual yang mereka peragakan dalam proses berladang hendak menunjukkan keterbukaan pada Yang Ilahi, yang mereka sebut dengan Petara Raja Juzvata. Sekaligus juga sebagai rasa hormat, sembah dan puji kepada Sang Petara yang telah menganugerahkan alam sebagai tempat untuk berladang. Ritual selalu melibatkan seluruh aspek jasmaniah manusia. Gestur-gestur dan simbol-simbol badaniah, tarian, nyanyian, permainan alat-alat musik sesungguhnya hendak menghantar manusia kepada kontak dengan yang Ilahi itu sendiri. ${ }^{19}$ Dengan mengadakan ritual orang menyatakan, mengungkapkan dan mementaskan iman mereka. Ritual adalah perbuatan penyuci peristiwa penting dalam kehidupan manusia menurut cara tertentu dan secara berkala. ${ }^{20}$ Tujuan lain dari upacara keagamaan ialah untuk menjamin keberlangsungan hidup mereka dari satu generasi ke generasi selanjutnya. ${ }^{21}$

Frase "menurut cara tertentu" hendak mengungkapkan bahwa pengungkapan diri dan komunitas yang dikemas dalam sebuah ritual adalah sebuah seni. Dengan seni hendak mengatakan bahwa manusia merayakan eksistensinya di dunia ini dalam relasinya dengan sesama dan alam lingkungan, dengan diri sendiri dan yang ilahi. Karena itu, beberapa peristiwa penting dalam hidup: kelahiran, memasuki usia dewasa, pernikahan, kematian selalu dirayakan secara meriah dan komunal serta kaya akan penggunaan simbol-simbol. Konsili Vatikan II menegaskan bahwa melalui kebudayaan manusia dapat menuju kepenuhan kemanusiaannya yang sejati, yakni dengan memelihara apa yang serba baik dan bernilai pada kodratnya. ${ }^{22}$

Pemahaman diri lewat tindakan nyata secara simbolis mengingatkan bahwa manusia adalah makhluk simbolis (homo symbolicus). Homo symbolicus, menurut Gerald O'Collins, merupakan salah satu kondisi yang tak boleh diabaikan dalam memahami manusia yang menerima pewahyuan diri Allah dengan penuh iman. Manusia secara esensial ialah makhluk simbolis, dan karena itu mengekspresikan dirinya dalam tindakan-tindakan simbolis. ${ }^{23}$ Apa yang menjadi perhatian pokok (ultimate concern) manusia, demikian tulis Paul Tillich, haruslah diekspresikan secara simbolis, karena bahasa simbol sendirilah yang dapat mengekspresikan perhatian tersebut. Karena, salah satu karakteristik dari

19 Lih. "Methodology: Asian Christian Theology. Doing Theology in Asia Today," FABC Paper No. 96, 95.

20 G. van Schie, Hubungan Manusia dengan Misteri segala Misteri (Jakarta: Fidei, 2008), 171.

21 Yekti Maunati, Identitas Dayak: Komodifikasi dan Politik Kebudayaan, (Yogyakarta: Lkis, 2004), 82.

22 Gaudium et Spes, 53.

23 Lih. Gerald O'Collins, Rethinking Fundamental Theology. Toward a New Fundamental Theology (Oxford: University Press, 2011), 40. 
simbol ialah membuka tataran realitas yang tertutup bagi manusia. ${ }^{24}$ Melalui bahasa-bahasa simbolis, manusia menemukan medium untuk mengalami Yang Transenden. ${ }^{25}$

Kedua, beduruk sebagai harmonisasi dengan sesama manusia. Tradisi beduruk menampilkan dengan gamblang hasrat manusia untuk membangun keharmonisan dengan sesama. Manusia Indonesia umumnya, dan suku Dayak khususnya sangat menjunjung tinggi semangat gotong royong. Setiap daerah di Nusantara menampilkan ciri khasnya masingmasing dalam memaknai semangat gotong-royong tersebut.

Kembali ke tradisi beduruk. Untuk memahami bagaimana beduruk menjadi panggung bagi warga untuk menciptakan keharmonisan, kita dapat melihat kembali kepada sifat keterbukaan dari beduruk itu sendiri. Beduruk terbuka untuk siapa saja tanpa memandang status sosial atau hubungan kekeluargaan. Baik laki-laki maupun perempuan sama-sama terlibat dalam aktivitas beduruk ini dengan memainkan peran dan tugasnya masing-masing. Keterbukaan ini tentu saja membuka kesempatan yang seluas-luasnya bagi warga untuk menjalin relasi dan kerja sama dengan siapa saja.

Absennya perbedaan status sosial serta peminggiran hubungan kekeluargaan dalam beduruk menjadi salah satu faktor yang berperan penting dalam terciptanya keharmonisan. Beduruk, meski selalu dilaksanakan secara berkelompok, tidak mengenal yang namanya struktur organisasi yang ketat dan tertata rapi layaknya sebuah organisasi pada umumnya. Semua adalah anggota yang sama kedudukan dan perannya. Setiap anggota hanya akan memainkan peran yang dominan ketika ladangnya mendapat giliran untuk dikerjakan. Peran ini pun tidak dipandang sebagai dominasi absolut terhadap anggota-anggota lain. Kontrol dan dominasi yang ia tunjukkan hanya sebatas dipahami untuk memperlancar jalannya proses pengerjaan ladang.

Keharmonisan juga terpancar lewat rasa saling memiliki di antara sesama anggota beduruk. Setiap anggota selalu menganggap yang lain sebagai saudara dan keluarga sendiri. Demikian juga dengan ladang orang lain selalu dilihat sebagai ladang sendiri. Sehingga di ladang siapa pun, mereka akan bekerja secara total dan penuh dengan tanggung jawab. Dengan mengadakan beduruk, mereka memiliki satu tujuan yakni agar pengolahan ladang semua anggota bisa selesai tepat waktu dan bisa menghasilkan panen yang baik. Karena itu, ketika ada salah satu anggota atau salah satu warga, dan hal ini seringkali terjadi, pekerjaan

24 Lih. Paul Tillich, Dynamics of Faith (New York: Harper Torchbooks, 1958), 41-42.

25 Teologi Simbol merupakan salah satu jalan yang ditekankan oleh Federasi Konferensi Dewan Uskup Asia (FABC) dalam pendekatan terhadap Yang Suci, FABC Paper, No. 96, 88. 
ladangnya masih cukup banyak, maka anggota/warga lain akan dengan sukarela mengulurkan tangan untuk membantu. ${ }^{26}$

Kerelaan untuk membantu yang lahir dari rasa saling memiliki merupakan bentuk solidaritas dalam beduruk. Solidaritas, demikian ditegaskan oleh Paus Yohanes Paulus II, merupakan tekad yang teguh dan tabah untuk membaktikan diri kepada kesejahteraan umum, artinya: kepada kesejahteraan semua orang dan setiap perseorangan, karena kita ini semua sungguh bertanggung jawab atas semua orang. Solidaritas membantu kita memandang "pihak lain" - entah itu pribadi, masyarakat atau bangsa - tidak sebagai semacam alat belaka, beserta kemampuan kerja dan kekuatan fisiknya untuk dieksploitasi dengan biaya murah, kemudian disingkirkan kalau sudah kehilangan faedahnya, melainkan sebagai "sesama" kita, sebagai "penolong" (bdk. Kej 2:18-20), untuk menjadi mitra usaha yang sederajat dengan kita pada perjamuan kehidupan, atas undangan Allah yang sama-sama ditujukan kepada semua orang. ${ }^{27}$ Solidaritas menjadi begitu penting karena "damai merupakan buah solidaritas" (Opus solidaritatis pax). ${ }^{28}$

Keharmonisan beserta semangat kekeluargaan dan persaudaraan tidak padam saat beduruk selesai, tapi berlanjut dan meresapi kehidupan bersama sehari-hari. Hampir tak ada satu pun peristiwa hidup yang tak dilaksanakan atau dirayakan secara komunal. Semua ini tidak ada tujuan lain selain hendak memperlihatkan bahwa sebuah komunitas akan menjadi kuat bila anggota-anggotanya hidup harmonis dan mau hidup untuk orang lain. Hal ini senada dengan yang disampaikan oleh Konsili Vatikan II dalam Konstitusi Pastoral tentang Gereja di Dunia Dewasa ini yang menegaskan, "...bahwa manusia yang di dunia ini merupakan satusatunya makhluk yang oleh Allah demi dirinya sendiri, tidak dapat menemukan diri sepenuhnya tanpa dengan tulus hati memberikan dirinya". ${ }^{29}$

Memahami manusia dari sudut pandang sebagai makhluk sosial rasanya belum lengkap bila kita tidak melihat martabat pribadi manusia itu sendiri. Suku Dayak juga mengenal adanya kisah penciptaan manusia. Dari kisah penciptaan itu, manusia diyakini sebagai ciptaan yang paling mulia dan sempurna. Dia haruslah menjadi teladan bagi ciptaan yang lain. Menjadi teladan dimaksudkan bahwa manusia harus selalu mengusahakan cinta kasih, perdamaian, kebenaran dan keadilan dalam hidup sehari-hari. ${ }^{30}$

26 Bantuan ini merupakan salah satu bentuk dari besaup.

27 Ensiklik Sollicitudo Rei Socialis, 38.

28 Ensiklik Sollicitudo Rei Socialis, 39.

29 Gaudium et Spes, 24.

30 Harapan terhadap manusia sebagai ciptaan yang paling mulia dan sempurna, dalam mitos 
Manusia, dalam pemahaman suku Dayak, terdiri atas badan dan jiwa yang membentuk kepribadiannya secara utuh. Hadirnya unsur jiwa ini, dalam masyarakat Dayak, memampukan mereka membaca atau menafsirkan kehadiran-kehadiran yang transenden dalam peristiwa atau gejala alam. Dalam suku Dayak di Dusun Medang, jiwa disebut dengan semengat. Semengat ini diyakini sebagai sarana yang dapat digunakan untuk berkomunikasi dengan Petara Raja Juzvata atau dengan alam gaib/ roh leluhur. Semengat itu pula yang memampukan mereka menangkap fenomena alam yang bisa menjadi berkat maupun menjadi kutuk.

Kemampuan tersebut, sayangnya, seringkali menjadi penghalang bagi manusia dalam mengamalkan kasih dalam hidup sehari-hari. Untuk mengasihi Allah dan sesama secara bebas, warga Medang seringkali terkurung dalam rasa takut. Rasa takut itu diakibatkan adanya malapetaka, celaka, roh yang nakal, leluhur yang marah, arwah yang belum tenang, yang mereka alami dalam hidup sehari-hari. Namun di sinilah letak peran Kekristenan, sebagaimana ditulis oleh Y. Boelaars, bahwa dalam agama Kristen petani menemukan seorang Allah-Pencipta-Bapa yang penuh kasih kepada umat-Nya sehingga manusia berani menyerahkan diri kepada-Nya dengan harapan akan selamat walaupun bencana dan malapetaka berlangsung terus. Namun, kebaikan sempurna Allah menebus petani dari ketakutan-ketakutan yang membuat mereka merasa tidak bebas mengasihi Allah dan sesama. ${ }^{31}$

Ketiga, beduruk sebagai harmonisasi dengan alam. Alam dan suku Dayak tak akan pernah dapat dipisahkan. Sudah sejak zaman leluhur alam menjadi penopang hidup yang tak tergantikan. Sadar akan hal ini, para leluhur mewariskan kebijaksanaan-kebijaksanaan yang bisa menjadi

penciptaan Kaharingan, terangkum dalam kata-kata ini: “Bitim batakuluk bangun tarajun ambun, baramate ungkal bulau pungkal raja, bakining bulau batutuk sangkalemu, bajela bulau batangep rabia, baiweh Nyalung Kaharingan Belum, basilu ruhung bataji pulang, bakatetes hinting Buno panjang, baratap hinting kamarau ambu, batatutuh bulau lelak bendang, batingkai rabia bahinis kereng, baragana anak antang baputi, belum balahap limu-limut bulue, hapanduyan Nyalung Kaharingan Belum, hapupuk guhung paninting aseng, tantausik Jata - Hatalla". Artinya: "Jadilah manusia yang mempunyai akal pikiran seperti teraju yang adil dan timbangan yang benar, mempunyai pandangan yang luas. Ia pandai melihat dan memilih mana yang benar dan mana yang salah, mana yang adil dan mana yang tidak adil. Cahaya matanya memancarkan cahaya keadilan dan perlindungan, rasa aman dan rasa bakti. Apa yang diucapkannya benar dan berguna. Lidahnya hanya mengucapkan hikmat dan kebenaran, perdamaian. Air liurnya mengalirkan air kehidupan yang tidak kering-keringnya. Tangan dan segala gerakannya penuh budi dan perdamaian. Pandai memutuskan segala perkara dengan adil dan jujur serta berbuah kemakmuran yang merata, ia selalu beriman, menjadi contoh dan teladan bagi sesama umat manusia, disenangi dan disegani di manapun ia berada. Ia selalu membersihkan dan menyucikan dirinya dan jiwanya. Dengan demikian ia selalu diberkati dan diberikan rahmat oleh Yang Mahasuci - Tuhan. Tjilik Riwut, Menyelami Kekayaan Luhur, (Palangka Raya: PUSAKALIMA, 2003), 482.

31 Y. Boelaars, Kepribadian Indonesia Modern (Jakarta: Gramedia, 1984), 89. 
penuntun bagi keturunan-keturunan yang kemudian, khususnya dalam mengolah alam.

Kebijaksanaan ini diperlukan mengingat alam bisa kapan saja mendatangkan bencana bagi manusia. Masyarakat suku Dayak juga sadar akan hal ini. Karena itu, sebelum mulai bekerja mereka berdoa, "Kami mohon berkat, kami minta selamat, agar jangan disimbat ranting kasar, ditimpa kayu besar, terluka pisau simpai, tertimpa kapak bertangkai".

Lalu bagaimana masyarakat Dayak menjaga keharmonisan dengan alam itu sendiri? Keharmonisan ini, pertama-tama, dapat dilihat dari pandangan orang Dayak tentang alam itu sendiri. Kehidupan seharihari suku Dayak masih kuat dipengaruhi oleh cara pandang kosmis. ${ }^{32}$ Cara pandang ini meyakini ketakterpisahannya antara realitas kosmos (manusia dan dunianya) serta realitas transenden. Dengan menghidupi pandangan ini, manusia menaruh hormat yang tinggi kepada kekuatankekuatan gaib dan roh leluhur.

Dalam konteks aktivitas berladang, rasa hormat tersebut ditampilkan lewat berbagai ritual yang wajib harus dilakukan. Ambil sebagai contoh ketika warga hendak membuka lokasi baru untuk berladang. Dalam keyakinan orang Dayak di dusun Medang, dan dalam beberapa suku Dayak lainnya ketika membuka lokasi tidak boleh mengabaikan tandatanda dari alam. Salah satu tanda alam yang masih diyakini kebenarannya ialah suara burung. ${ }^{33}$ Warga dusun Medang meyakini ada beberapa jenis burung yang suaranya merupakan pertanda buruk. Sehingga, saat mereka membuka sebuah lokasi untuk berladang dan terdengarlah oleh mereka suara-suara burung tersebut, maka mereka tidak boleh membuka lahan di situ. Kalau suara burung itu diabaikan dapat mendatangkan akibat yang fatal terutama bagi segenap anggota keluarga. Mimpi juga kadang memainkan faktor yang menentukan saat warga hendak mulai berladang. Mimpi diyakini sebagai sarana yang dipakai oleh leluhur untuk

32 Federasi Konferensi Dewan Uskup Asia menekankan bahwa dalam berteologi dalam konteks Asia, cara pandang kosmis ini haruslah diperhatikan. Demikian ditegaskan: "Semua tradisi di Asia memiliki sebuah pandangan kosmis yang mengintegrasikan pertanyaan tentang keselamatan manusia ke dalam sebuah pandangan yang menyatu dengan seluruh kosmos. Pandangan ini sesungguhnya datang dari tradisi-tradisi primitif di Asia, yang para pengikutnya dekat dengan ibu pertiwi dan menaruh hormat yang dalam terhadap alam, yang dalam bahasa sekarang dikenal dengan pandangan ekologis. Tradisi ini masih hidup sampai hari ini di antara beberapa suku di Asia". Lih. FABC Paper No. 96, 3.

33 Dalam suku Dayak Desa di dusun Medang ada lima jenis burung yang bisa menjadi pertanda, yaitu: ketupung, gurak, bejampung, ngemuas dan papau. Saat membuka lokasi baru untuk berladang begini syaratnya: Kalau ketupung berbunyi hanya sekali itu artinya pertanda tidak baik. Kita harus memukul sarung parang beberapa kali atau bersiul memanggilnya agar dia menyahut isyarat yang kita keluarkan. Kalau burung itu bersuara lagi, itu artinya kita bisa membuka lahan di situ. Tetapi kalau tidak ada suara sahutan, maka kita tidak boleh membuka lahan di situ. Wawancara dengan Bpk. Martinus Indat. 
menyampaikan pesan. Karena itu, kalau seseorang mengalami mimpi buruk, mimpi mengalami kecelakaan, sebagai contoh, maka pengerjaan ladang pada tempat yang telah ditentukan tidak akan dilanjutkan. Bahkan dari beberapa pengalaman yang pernah penulis lihat, warga akan menghentikan proses berladang, meski sudah pada tahap yang cukup jauh, ketika mereka mengalami mimpi buruk dan sejenisnya. ${ }^{34}$ Sama seperti dalam kasus suara burung, pengabaian terhadap mimpi juga bisa mendatangkan bencana atau penyakit, bukan hanya bagi keluarga, melainkan juga bagi anggota masyarakat yang lain.

Kemudian, bagaimana memahami keharmonisan dengan alam tercipta lewat tradisi beduruk? Sebelum sampai pada pembahasan tersebut, beberapa mungkin akan bertanya bagaimana mungkin keharmonisan ini akan tercipta sementara dengan berladang warga sendiri malah "merusak" hutan? Tidakkah justru ada kontradiksi dalam aktivitas berladang itu sendiri?

Dalam hal ini mungkin jangan terlalu cepat menyalahkan para petani atas kerusakan hutan dan lingkungan. Konferensi Wali Gereja Indonesia (KWI) dalam Nota Pastoral 2013 dengan tema: KETERLIBATAN GEREJA DALAM MELESTARIKAN KEUTUHAN CIPTAAN mencatat beberapa aktivitas yang merusak lingkungan hidup seperti: pertambangan, perkebunan, industri kehutanan, pencemaran tanah, pencemaran udara, pencemaran air, sampah dan perubahan iklim. Semua aktivitas tersebut menyumbang lewat caranya masing-masing terhadap kerusakan lingkungan.

Karena artikel ini berhubungan dengan hutan, maka hanya dua aktivitas yang menjadi sorotan dan menjadi bahan perbandingan, mengingat seringkali orang Dayak menjadi kambing hitam atas kerusakan hutan dengan praktik ladang berpindahnya. Dari sektor perkebunan, KWI mencatat berdasarkan data Dirjen Perkebunan bahwa usaha perkebunan dalam skala besar jauh lebih berkembang dibangdingkan perkebunan rakyat. Data menunjukkan bahwa pertambahan luas perkebunan kelapa sawit selama 10 tahun terakhir meningkat $88 \%$ yaitu dari 4,15 juta hektar di tahun 2000 menjadi 7,8 juta hektar pada tahun 2010. Sementara luas perkebunan karet relatif tetap dari 3,37 juta hektar pada tahun 2000 menjadi 3,44 juta hektar pada tahun 2010.35 Gereja, di satu sisi, mengakui keberadaan perkebunan sawit karena telah menyediakan kontribusi yang besar dalam penyediaan lapangan kerja, memberikan nilai tambah terhadap pendapatan daerah dan ikut

34 Dalam beberapa kesempatan, bila kasus ini terjadi, keluarga yang bersangkutan akan melakukan ritual dan mempersiapkan sesajen sesuai dengan apa yang dipesankan dalam mimpi. Namun, ada juga beberapa jenis mimpi yang memang harus ditaati larangannya.

35 Keterlibatan Gereja Dalam Melestarikan Keutuhan Ciptaan, (Jakarta: Nota Pastoral KWI, 2013), 8. 
menumbuhkan sektor jasa transportasi. Namun di lain sisi, Gereja juga melihat adanya masalah serius, yakni soal penghargaan terhadap hak hidup manusia. Pemberian ijin untuk perkebunan sawit seringkali tidak mengakui hak hidup masyarakat adat maupun masyarakat lain yang sudah lebih dahulu tinggal dan beraktivitas di situ. Masyarakat setempat seringkali menjadi budak di tanah sendiri. Kerusakan lingkungan akibat penggunaan pupuk dan pestisida yang terus menerus, pengambilan air tanah untuk keperluan tanaman merupakan masalah lain yang harus diderita oleh alam dan manusia. ${ }^{36}$

Sementara itu dari sektor industri kehutanan, KWI juga mencatat semakin meningkatnya kerusakan hutan akibat penebangan kayu yang berlebihan dan praktik illegal logging. Mengutip data dari Kementerian Kehutanan, KWI melaporkan bahwa luas lahan kritis dan sangat kritis tahun 2011 telah mencapai 29,3 hektar. Kerusakan tersebut tidak lepas dari peran para pengambil kebijakan yang sering hanya mendasarkan kebijakan pada pertimbangan keuntungan ekonomis semata. Sanksi hukum terhadap pelanggar peraturan tentang industri kehutanan juga masih belum diterapkan dengan semestinya. Kesadaran masyarakat yang masih kurang terhadap pentingnya alam untuk kehidupan, juga menjadi penyebab lain kerusakan hutan. ${ }^{37}$

Bila demikian kenyataannya, apakah aktivitas berladang dapat dikatakan sebagai bentuk pengerusakan hutan? Apakah para petani termasuk dalam golongan orang yang belum sadar akan pentingnya hutan? Pertanyaan ini mengemuka mengingat ketika terjadi bencana asap, para petanilah yang sering menjadi kambing hitam karena sistem ladang berpindah yang mereka praktekkan. Namun, bila melihat perlakuan para petani terhadap alam rasanya juga terlalu naif bila mengatakan kalau mereka belum sadar akan pentingnya hutan. Berbagai kearifan yang mereka tunjukkan adalah bukti dari kesadaran tersebut.

Pertama-tama yang harus disadari ialah bahwa aktivitas berladang tidak dilandasi oleh motif keuntungan ekonomis. Tujuan berladang hanyalah semata-mata untuk menghasilkan padi yang kemudian diolah menjadi nasi sebagai sumber makanan utama sehari-hari. Keluarga yang mendapat hasil panen yang banyak tidaklah dibayangkan akan mendapat uang yang banyak pula, karena memang padi yang didapat bukan untuk diperjualbelikan. Karena itu, para petani tidak pernah membuka lahan dalam skala besar sebagaimana yang dijumpai dalam perkebunan sawit. Mereka juga menggunakan pupuk dan pestisida masih dalam takaran yang wajar, sehingga tidak berpotensi merusak lingkungan dan ekosistem lain.

36 Ibid.

37 Ibid. 
Pembuatan peladak merupakan salah satu cara yang digunakan oleh warga untuk mencegah kerusakan hutan. Peladak merupakan jalur yang dibuat mengelilingi ladang, lebarnya berkisar antara 0,5-1 meter, yang fungsinya untuk mencegah api menjalar keluar ketika ladang dibakar. Saat membakar ladang warga akan berdiri di jalur ini untuk memastikan api tidak menjalar ke tempat lain. Mengingat adanya risiko kebakaran hutan dari aktivitas berladang ini, proses pembakaran lahan selalu melibatkan orang ramai. Warga tidak pernah, dan memang tidak diizinkan, membakar ladang miliknya hanya seorang diri. Karena itu, hukuman adat menanti mereka, yang karena kelalaiannya saat membakar ladang, menyebabkan kerusakan lahan atau kebun milik orang lain. Begitulah beberapa kearifan yang ditunjukkan oleh warga dalam usaha menjaga kelestarian alam, serta menciptakan relasi yang harmonis dengan alam.

\section{Simpulan}

Tradisi beduruk sesungguhnya lahir dari kesadaran warga akan beratnya pekerjaan sebagai petani ladang. Beduruk dilakukan karena dipandang sebagai cara yang efektif dan efisien dalam mengolah lahan agar pekerjaan bisa menjadi lebih ringan. Namun, beduruk tidak hanya dipahami sebatas meringankan beban pekerjaan saja. Lebih dari itu, lewat aktivitas beduruk, yang mungkin bagi warga hanya sekadar sebuah rutinitas belaka, sesungguhnya warga disadarkan betapa pentingnya selalu menjaga keharmonisan, kerukunan, keserasian, kedamaian, persahabatan dengan Sang Pencipta, dengan sesama dan dengan alam. Ketiga bentuk harmoni ini berkaitan erat satu sama lain. Jika harmoni dengan yang satu tercipta, maka harmoni dengan yang lainnya dengan sendirinya juga akan terbangun.

Karena itu, ada beberapa poin yang dapat disimpulkan dari apa yang telah dipaparkan di atas. Pertama, manusia adalah pribadi bagi Tuhan. Mitos kisah penciptaan dalam suku Dayak meyakini bahwa manusia merupakan ciptaan yang mulia dan sempurna dan harus menjadi teladan bagi ciptaan yang lain. Manusia juga memiliki jiwa (semengat) yang memampukannya menangkap kehadiran yang transenden dalam hidup sehari-hari. Konsep dan keyakinan ini senada dengan pandangan Gereja sendiri tentang manusia. Gereja mengajarkan bahwa manusia adalah satu-satunya makhluk yang diciptakan secitra dengan Allah (bdk. Kej 1:27). Diciptakan menurut gambar dan rupa Allah membuat manusia terbuka atau terarah kepada yang transenden. Manusia memang hidup dalam keterbatasan ruang dan waktu, bahkan dirinya pun adalah makhluk yang terbatas. Namun, manusia tetap dipanggil untuk "melambungkan suaranya untuk dengan bebas memuliakan Sang 
Pencipta...Maka dari itu martabat manusia sendiri menuntut, supaya ia meluhurkan Allah dalam badannya" ${ }^{38}$

Sebagai citra Allah, manusia mempunyai martabat sebagai pribadi yang mampu mengenali dirinya, menyadari kebersamaan dirinya dengan orang lain, dan bertanggung jawab atas makhluk ciptaan lain. Manusia adalah rekan kerja Allah dalam menata, menjaga, memelihara dan mengembangkan seluruh alam semesta ini. Allah memberikan kepercayaan kepada manusia untuk memelihara dan mengolah dengan bijaksana alam semesta ini serta berupaya menciptakan hubungan yang harmonis di antara semua ciptaan (bdk. Kej 2:15). ${ }^{39}$ Paus Yohanes Paulus II mengajarkan bahwa ketika kita berdamai dengan Tuhan, kita akan mampu mengabdikan diri untuk membangun perdamaian dengan semua ciptaan yang tidak dapat dipisahkan dari perdamaian di antara semua manusia. ${ }^{40}$

Kedua, manusia adalah makhluk sosial. Kehadiran tradisi beduruk di dusun Medang semakin menegaskan kebenaran akan konsep ini. Dengan menciptakan suatu bentuk kerja sama manusia menyadari dirinya sebagai makhluk yang tidak bisa hidup tanpa orang lain. Dengan adanya kerja sama manusia diajak membuka diri terhadap sesama. Dengan mau membuka diri, maka seseorang bisa belajar dari orang lain, terutama bagaimana teknik atau cara yang tepat dalam mengolah ladang. Namun, lebih dari sekadar sebagai ajang untuk menimba keterampilan dari orang lain, beduruk sesungguhnya hendak mengajak orang untuk memaknai bahwa kepenuhan hidup akan tercapai bila mau memberikan dirinya bagi orang lain dan berkorban bagi sesamanya. Kitab Kejadian mencatat, "Adalah tidak baik kalau manusia itu seorang diri saja" (Kej 2:18). Kenyataan ini menunjukkan bahwa sejak awal penciptaan, Allah menjadikan manusia dalam kondisi untuk siap saling menolong, dan itu berarti keterbukaan akan yang lain. ${ }^{41}$

Ketiga, manusia sebagai homo ecologicus. Dengan homo ecologicus hendak dimaksudkan bahwa manusia sungguh menyatu dengan realitas dunia. Penyatuan dengan realitas dunia ini beralasan karena kosmos dipandang sebagai ciptaan ilahi. Kosmos, karena itu, selalu dikaitkan dengan wujud ilahi dan pelbagai nilai yang terkandung di dalamnya. Alam memiliki jiwa tersendiri, bersifat sakral dan kerap dipersonifikasi sebagai wujud yang mengatasi kuasa manusiawi, yang kepadanya

38 Gaudium et Spes, 14.

39 Keterlibatan Gereja Dalam Melestarikan Keutuhan Ciptaan, 10.

40 Pope John Paul II, Message for the Celebration of the World Day of Peace. Peace with God the Creator, Peace with All the Creation (Vatican 1989), 16.

41 T. Krispurwana Cahyadi, Yohanes Paulus II. Gereja, Teologi dan Kehidupan (Jakarta: Obor, 2007), 29. 
manusia harus menyesuaikan diri, memberikan hormat dan sembah. Pandangan hidup yang demikian mendorong manusia untuk mengembangkan sikap harmoni terhadap alam. Harmoni atau keseimbangan menjadi keutamaan, dan karena itu relasinya dengan dunia lainnya pun apresiasif. Jika keharmonisan ini diganggu, manusia akan mengalami malapetaka (chaos). ${ }^{42}$

Keempat, soal iman dan budaya. Soal ini saya tambahkan mengingat pentingnya budaya dalam karya pastoral Gereja. Dalam pemaparan di atas disebutkan bahwa dalam beberapa kesempatan Gereja hadir dalam kehidupan para petani. Kehadiran itu tidak lain hendak menunjukkan betapa Gereja menghargai budaya setempat. Paus Yohanes Paulus II menegaskan: "Kebudayaan adalah ruang vital di mana manusia berjumpa langsung dengan Injil...Dalam proses menjumpai pelbagai kebudayaan dunia yang berbeda, Gereja tidak hanya menyalurkan kebenaran-kebenaran dan nilai-nilai yang ia miliki serta memperbaharui kebudayaan tersebut dari dalam, tetapi mengangkat juga dari pelbagai kebudayaan unsur-unsur positif yang sudah terkandung di dalamnya. ${ }^{43}$

\section{Bibliografi}

Andasputra, Nico \& Stepanus Djuweng (eds.). Manusia Dayak, Orang Kecil yang Terperangkap Modernisasi. Pontianak: Institut Dayakologi, 1996.

Boelaars,Y. Kepribadian Indonesia Modern. Jakarta: Gramedia, 1984.

Cahyadi, T. Krispurwana. Yohanes Paulus II Gereja, Teologi dan Kehidupan. Jakarta: Obor, 2007.

Federation of Asian Bishop's Conferences. Paper No.96 Methodology: Asian Christian Theology. Doing Theology in Asia Today. Hong Kong: 2000.

Florus, Paulus. "Puyang Gana: Sang Penjaga Bumi." Minum Dari Sumber Sendiri, Dari Alam Menuju Tuhan. Benny Phang \& Valentinus (eds.). Malang: STFT Widya Sasana, 2011.

Hayong, Bernard S, “Ritus Hode Ilu dalam Masyarakat Lewoingu: Antara Tindakan Superstisi dan Realitas Numinus". Jurnal of Ledalero 10, no. 2 (2011): 189-200.

Maunati, Yekti. Identitas Dayak: Komodifikasi dan Politik Kebudayaan. Yogyakarta: Lkis, 2004.

Nota Pastoral Keterlibatan Gereja dalam Melestarikan Keutuhan

42 Bernard S. Hayong, "Ritus Hode Ilu dalam Masyarakat Lewoingu: Antara Tindakan Superstisi dan Realitas Numinus," Jurnal Ledalero 10, no. 2 (2011), 195.

43 Bdk. Yohanes Paulus II, Ecclesia in Asia (Vatican 1999), 21. 
Ciptaan. Jakarta: Konferensi Wali Gereja Indonesia. 2013.

O'Collins, Gerald. Rethinking Fundamental Theology. Toward a New Fundamental Theology. Oxford: University Press, 2011.

Pope John Paul II. Apostolic Exhortation Ecclesia in Asia. (6 November 1999).

Pope John Paul II. Ensiklik Sollicitudo Rei Socialis. (30 Desember 1987).

Pope John Paul II. Message for the Celebration of the World Day of Peace. Peace with God the Creator, Peace with All the Creation. (8 December 1989).

Riwut, Tjilik. Menyelami Kekayaan Leluhur. Palangka Raya: Puskalima, 2003.

Schie, G. Van. Hubungan Manusia dengan Misteri segala Misteri. Jakarta: Fidei, 2008.

Tillich, Paul. Dynamics of Faith. New York: Harper Torchbooks, 1958.

\section{Sumber Internet}

https://ibanology.wordpress.com/2013/11/14/iban-ibanic-and-ketungau. Akses: $3 / 02 / 2019$. 